\title{
PENINGKATKAN PENERIMAAN RUMAH SAKIT PADA \\ RUMAH SAKIT UMUM DAERAH HASANUDDIN DAMRAH (RSUD-HD) KABUPATEN BENGKULU SELATAN
}

\section{Improving Acceptancy Hospital at Hasanuddin Damrah Public Region Hospital in South Bengkulu Regency}

\section{Rahmad Harry Dapin', Sri Hartoyo², Harianto ${ }^{3}$}

${ }^{1}$ Rumah Sakit Umum Daerah Hasanuddin Damrah, Kabupaten Bengkulu Selatan. E-mail : harrydapin@aol.com

2Staff Pengajar Departemen Ilmu Ekonomi, Fakultas Ekonomi dan Manajemen IPB. E-mail : shty@indo.net.id ${ }^{3}$ Staff Pengajar Departemen Agribisnis, Fakultas Ekonomi dan Manajemen IPB. E-mail :

harianto.ipb@gmail.com

\begin{abstract}
The application of financial management system in public service at RSUD-HD cause all the operational activities is funded by the acceptance. Based on this, it is need strategy to improve the acceptance. The purpose of this research is to analize acceptancy potential and evaluate acceptance work to reach the target of acceptance, analize which unit that had reached the target or hadn't reached the target, and how much the differences the increasing or decreasing from the target that has been determined, identification the cause of the target that has reached and hasn't reached and to formulate what strategy should be determined in improving acceptancy. The research is done in Hasanuddin Damrah Public Region Hospital in South Bengkulu Regency. The data primary is got from direct interview while the data secondary is got from the report and some documents has been got from competent instance. The data is analyze by the acceptance of potential and worked analizing by using effectively ratio, growth ratio, and variance analysis. The result of the research are: 1) RSUD-HD has limited of counting acceptancy; 2) Acceptance of work in 2008-2011 inclined to the decrease and in 2012-2016 inclined to the increase; 3) Decreases the target determined is not the solution realization of overlapping the target; 4) Generally in 2012 the acceptance always has overlapped the target; 5) The management of acceptance hasn't the certain document yet. The main priority of strategy improving acceptance RSUD-HD is development strategy and improving the health service.
\end{abstract}

Keyword : acceptance working, acceptance potential, strategy improving acceptance.

\begin{abstract}
ABSTRAK
Penerapan Pola Pengelolaan Keuangan Badan Layanan Umum Daerah pada RSUD-HD mengakibatkan seluruh kegiatan operasional dibiayai dari penerimaan. Untuk itulah diperlukan strategi peningkatan penerimaan. Tujuan penelitian adalah menganalisis potensi penerimaan serta mengevaluasi kinerja penerimaan terhadap pencapaian target penerimaan, menganalisa unit mana yang targetnya tercapai/tidak tercapai dan seberapa besar selisih kenaikan/penurunannya dari target yang ditetapkan, mengidentifikasi penyebab terjadinya target tidak tercapai dan yang melampaui target serta merumuskan strategi apa yang harus diterapkan dalam rangka peningkatan penerimaan. Tempat kajian dilakukan di Kabupaten Bengkulu Selatan pada Rumah Sakit Umum Daerah Hasanuddin Damrah. Data primer diperoleh dari wawancara langsung, sedangkan data sekunder diperoleh dari laporan dan dokumen yang didapat dari berbagai instansi terkait. Data dianalisis dengan analisis potensi penerimaan dan analisis kinerja dengan memakai rasio efektifitas, pertumbuhan, dan selisih. Hasil yang didapat dari kajian ini : 1) RSUD-HD mempunyai keterbatasan dalam perhitungan potensi penerimaan, 2) Kinerja penerimaan tahun 2008 sampai dengan 2011 cenderung rendah, tahun 2012 sampai dengan 2016, cenderung tinggi, 3) Penurunan target penerimaan bukanlah solusi agar realisasi mampu melampaui target 4) Secara umum sejak tahun 2012 penerimaan selalu melebihi dari target, 4) Manajemen penerimaan belum mempunyai catatan yang begitu mendalam. Strategi prioritas utama peningkatan penerimaan RSUD-HD adalah Strategi Pengembangan dan peningkatkan pelayanan kesehatan
\end{abstract}

Kata kunci : kinerja penerimaan, potensi penerimaan, strategi peningkatan penerimaan 


\section{PENDAHULUAN}

Undang-Undang Dasar (UUD) Negara Republik Indonesia tahun 1945 pasal 28 ayat (1) menyebutkan bahwa setiap orang berhak memperoleh pelayanan kesehatan, dan dalam pasal 34 ayat (3) dinyatakan negara bertanggung jawab atas penyediaan fasilitas pelayanan kesehatan dan fasilitas pelayanan umum yang layak. Berbagai upaya telah dilakukan pemerintah untuk melaksanakan amanat tersebut diantaranya pembangunan berbagai fasilitas kesehatan seperti rumah sakit, puskesmas dan poskesdes. Pemerintah dalam upayanya melaksanakan amanat undang-undang tersebut telah mengeluarkan berbagai kebijakan melalui kebijakan anggarannya yaitu Anggaran Pendapatan Belanja Negara berupaya untuk lebih tinggi porsi pengganggarannya dari tahun ke tahun. Hal tersebut terlihat dimana pada tahun 2010 anggaran kesehatan hanya Rp. 33 triliun atau 3,2\% terhadap belanja negara meningkat pada tahun 2015 menjadi Rp. 71,1 triliun atau 3,5\%, terhadap belanja negara (Kemenkeu 2016). Adapun di tahun 2014 terjadi kenaikan yang cukup besar, hal tersebut dikarenakan adanya kenaikan APBN.

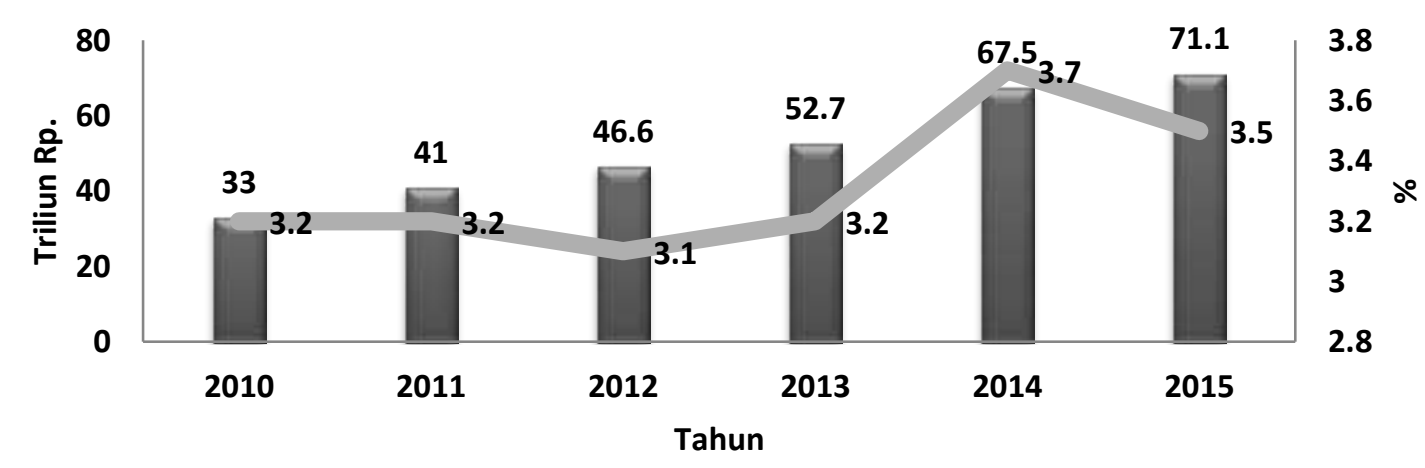

Anggaran Kesehatan $\quad \%$ terhadap Belanja Negara

Sumber : Kementerian Keuangan 2016.

\section{Gambar 1. Anggaran Kesehatan Nasional terhadap Belanja Negara Tahun 2010-2015}

Undang-Undang nomor 44 tahun

2009 (Pemerintah Republik Indonesia 2009) menyatakan rumah sakit sebagai salah satu fasilitas pelayanan kesehatan merupakan bagian dari sumber daya kesehatan yang sangat diperlukan dalam mendukung penyelenggaraan upaya kesehatan, sehingga dituntut dapat memberikan pelayanan berkualitas dalam menjalankan fungsinya sebagai tempat penyembuhan penyakit dan pemulihan kesehatan. Untuk itu rumah sakit memerlukan biaya operasional dan investasi yang besar dalam pelaksanaan kegiatannya, perlu didukung ketersediaan pendanaan yang cukup dan berkesinambungan (Restianto dan Bawono 2015).
Tahun 2014 merupakan tahun yang sangat penting dan strategis di bidang kesehatan, karena mulai diberlakukannya Jaminan Kesehatan Nasional (JKN) sebagaimana diamanatkan dalam Undang-Undang Nomor 24 Tahun 2011 tentang Badan Penyelenggara Jaminan Sosial. Dengan diberlakukannya JKN tersebut, semua rumah sakit baik milik pemerintah/swasta dapat melayani pasien yang dibayarkan oleh Badan Penyelengara Jaminan Sosial (BPJS), sehingga mengakibatkan tingkat kompetisi antar rumah sakit dalam pelayanan kesehatan akan semakin tinggi (Pemerintah Republik Indonesia 2011).

Untuk mendukung pemerintah 
berdasarkan Keputusan Bupati Bengkulu Selatan Nomor: 445/582 Tahun 2014 tentang Penetapan RSUD Hasanuddin Damrah sebagai Satuan Kerja Perangkat Daerah (SKPD) yang menerapkan Pola Pengelolaan Keuangan Badan Layanan Umum Daerah (Pemkab B/S 2014). RSUD-HD adalah Satuan Kerja SKPD di lingkungan Pemerintah Kabupaten Bengkulu Selatan yang menerapkan Pola Pengelolaan Keuangan. Dengan berubahnya RSUD-HD sebagai SKPD yang telah ada dan sudah menerapkan Pola Pengelolaan Keuangan BLUD maka seluruh kegiatan operasional dibiayai dari penerimaan yang dihasilkan dari hasil usaha operasional RSUD-HD (Kemendagri 2007). Agar penerimaan yang dihasilkan dari hasil usaha kegiatan operasional selalu meningkat dan dapat menutupi semua kegiatan operasional maka diperlukan suatu strategi bagaimana meningkatan penerimaan Rumah Sakit Umum Daerah Hasanuddin Damrah Kabupaten Bengkulu Selatan.

Otonomi daerah mendorong agar setiap daerah melakukan pembangunan dan pengembangan daerahnya masingmasing, hal ini membuat setiap daerah dituntut dapat mengelola sumber daya yang ada dengan maksimal. Begitu juga dalam hal sumber pendapatan yang berasal dari pelayanan kesehatan yang dihasilkan oleh RSUD-HD. Ditambah lagi semenjak RSUD sudah menjadi BLUD maka seluruh biaya operasionalnya berasal dari pendapatan yang diterimanya. Dengan kondisi ini maka Penerimaan yang dilaksanakan oleh RSUD-HD diharapkan trendnya akan selalu meningkat, seperti dapat dilihat pada Gambar 2.

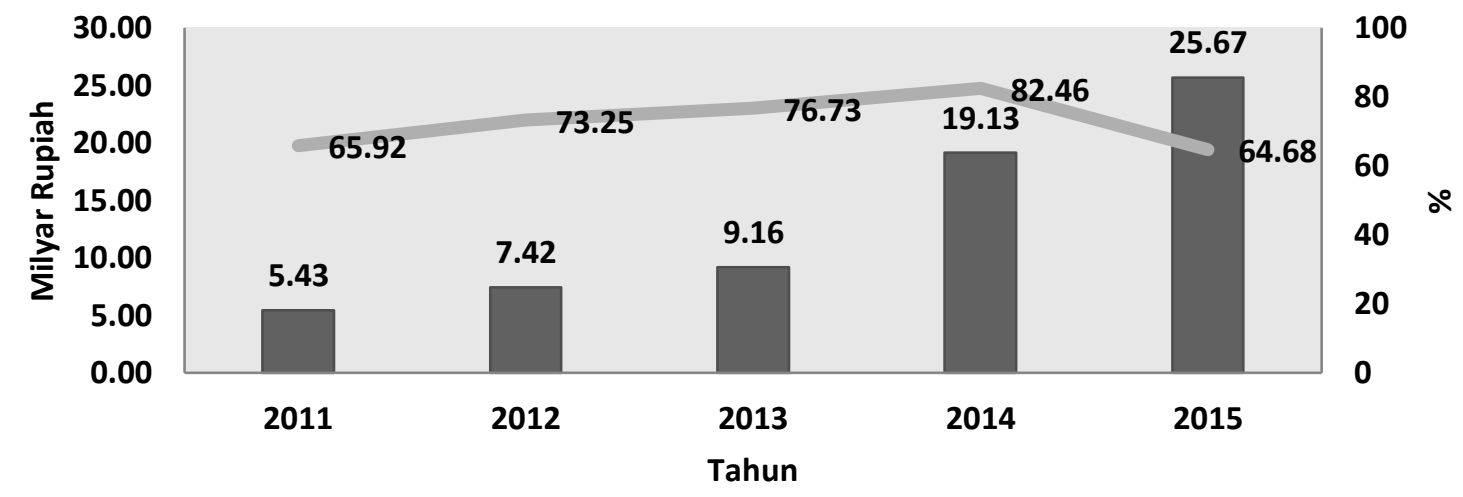

\section{Gambar 2. Kontribusi Penerimaan RSUD terhadap Retribusi Daerah 2011-2015}

Berdasarkan Gambar 2, terlihat secara jumlah penerimaan yang dilakukan RSUD-HD selalu meningkat, walaupun secara presentase di tahun 2015 terjadi penurunan. Walaupun meningkat masih harus dilihat kembali apakah semua potensi penerimaan yang ada telah tergali atau belum. Bisa jadi meningkatnya retibusi daerah dikarenakan peningkatan jumlah penduduk.

Dalam siklus pengelolaan keuangan pemerintah, perencanaan adalah siklus pertama yang dilakukan dalam rangka memetakan target dan pekerjaan apa yang akan dilaksanakanan dalam satu tahun anggaran. Setelah dilakukan perencanaan, maka tahap selanjutnya adalah pelaksanaan anggaran. Semua pendapatan dicatat dan dipertanggungjawabkan sesuai dengan peraturan yang ada, dari semua pendapatan yang terkumpul baik setiap bulan, triwulan, semester hingga akhirnya terkumpul menjadi satu tahun akan dilihat 
atau dibandingkan dengan pagu anggaran yang ditetapkan dalam perencanaan.

Realisasi penerimaan yang didapat dalam satu tahun tersebut merupakan akumulasi dari seluruh sektor pendapatan di RSUD-HD. Adapun sektor-sektor penerimaan di RSUD-HD adalah : Sektor pelayanan kesehatan yang terdiri dari sub sektor pelayanan rawat jalan dan sub sektor pelayanan rawat inap. Sektor sarana kesehatan yaitu terdiri sub sektor sarana penunjang medis dan sub sektor sarana penunjang non medis. Dari akumulasi seluruh sektor penerimaan tersebut, maka dicari dari sektor mana yang melebihi target yang ditetapkan, dan sektor mana yang kurang dari target yang ditetapkan, serta juga harus dilihat selisih kenaikan atau penurunannya.

Dengan melihat besaran selisih tersebut akan terlihat sektor mana yang selisihnya begitu besar baik itu selisih lebih/kurang terhadap pencapaian target yang ada, sehingga akan memudahkan pucuk pimpinan dalam mengambil keputusan dan tindakan dalam rangka perbaikan pelayananan kesehatan bagi masyarakat. Dengan mengetahui faktorfaktor penyebab dari selisih tersebut, akan memudahkan pengambil keputusan untuk menentukan strategi apa yang diambil sehingga pelayanan yang diberikan kepada masyarakat menjadi lebih baik, dimana akan memunculkan kepuasan masyarakat yang berdampak pula pada peningkatan penerimaan rumah sakit, maka tujuan dari penelitian ini adalah 1) Menganalisis besaran potensi penerimaan rumah sakit RSUD-HD serta mengevaluasi kinerja penerimaan rumah sakit terhadap pencapaian target penerimaan yang telah ditetapkan RSUDHD; 2) Menganalisa sub sektor/unit mana yang targetnya tercapai/tidak tercapai dan seberapa besar selisih kenaikan/penurunannya dari target yang ditetapkan; 3) Mengidentifikasi penyebab terjadinya target tidak tercapai dan yang melampaui target pada penerimaan dan merumuskan strategi yang harus diterapkan dalam rangka optimalisasi peningkatan penerimaan rumah sakit RSUD-HD.

\section{METODOLOGI}

Objek kajian adalah Penerimaan rumah sakit beserta komponen yang mempengaruhinya, tempat kajian dilakukan di wilayah Kabupaten Bengkulu Selatan. Responden dalam penelitian ini dibagi menjadi dua bagian. Pertama, responden di luar RSUD-HD, dimana responden ini merupakan pejabat pemerintah daerah yang dianggap berkaitan atau berpengalaman serta berkompeten untuk memberikan penilaian terhadap pembentukan BLUD dan proses penganggaran RSUD-HD yang terdiri atas : 1) Sekretaris Daerah; 2) Kepala Dinas Pendapatan, Pengelolaan Keuangan, dan Aset Daerah; 3) Kepala Badan Perencanaan Pembangunan.

Kedua, Responden di dalam RSUDHD. Dimana responden ini adalah Pejabat RSUD-HD yang merupakan orang-orang yang dianggap berkaitan atau berpengalaman serta berkompeten untuk memberikan penilaian terhadap elemen yang berpengaruh dalam peningkatan penerimaan RSUD-HD yang terdiri atas : 1) Direktur; 2) Kepala Bagian Tata Usaha; 3) Kepala Bidang Pelayanan; 4) Kepala Bidang Perawatan 5) Kepala Bidang Sarana dan Prasarana; 4) Kepala Sub Bagian Keuangan. Selain responden pejabat RSUD-HD juga melibatkan responden Petugas Penerimaan RSUDHD yang bertujuan untuk menganalisa kekuatan dan kelemahan permasalahan penerimaan di tingkat pelaksanaan penerimaan serta untuk menganalisa kisaran potensi penerimaan. Masingmasing sektor penerimaan akan dipilih 1 orang per sub sektor atau unit untuk diambil sebagai responden dengan pertimbangan 1 orang kepala sub sektor atau unit, administrasi penerimaan 1 orang, sehingga jumlah respondennya adalah 34 orang. 
Data yang dikumpulkan dalam rangka mendukung kajian ini yaitu data primer dan data sekunder. Data primer diperoleh dari wawancara langsung terhadap sumber informasi yang telah ditentukan, kemudian informasi tersebut dilakukan pencocokan dengan sumber data lain yang memiliki pengetahuan yang cukup tentang informasi tersebut sebagai langkah koreksi untuk menjamin reabilitas dan validitas data tersebut. Data primer juga didapat dari angket/kuesioner pada pihak yang terkait. Sedangkan data sekunder diperoleh dari laporan dan dokumen yang dikeluarkan oleh RSUDHD seperti data pendapatan, jumlah ruangan, fasilitas penunjang, tingkat kunjungan, dan lain-lain. Data sekunder juga didapat dari berbagai instansi terkait seperti dari Badan Perencanaan Pembangunan Daerah (Bappeda), Dinas Pendapatan, Pengelolaan Keuangan dan Aset Daerah (DPPKAD), Dinas Kesehatan (Dinkes), Dinas Pendidikan dan Budaya (Dinas Dikbud), Biro Pusat Statistik (BPS), Kementerian Keuangan, peraturan perundang-undangan, literatur, hasil kajian sejenis, dan informasi lainnya yang berhubungan dengan topik kajian.

Data primer dan sekunder yang didapat kemudian diolah dan dianalisis untuk mendapatkan rekomendasi sebagai strategi kebijakan pemerintah daerah dalam rangka peningkatan penerimaan rumah sakit pada RSUD-HD. Untuk mendapatkan strategi tersebut terdapat tahapan yang harus dilakukan. Tahap Pertama adalah melakukan analisis Perkiraan Potensi Penerimaan dan kinerja RSUD-HD. Menurut Mahmudi (2010) Potensi suatu penerimaan pajak/retribusi secara umum dapat dihitung dengan mengalikan tarif suatu pajak/retribusi dengan basis pajak/retribusi. Sementara itu, penentuan basis pajak/retribusi perlu dilakukan penghitungan secara obyektif.

\section{Potensi Pendapatan Retribusi $=$ Basis Retibusi X Tarif Retribusi}

Untuk analisis terhadap kinerja dilakukan dengan memakai rasio-rasio keuangan anatara lain (Kasmir 2008):

a. Rasio Efektifitas

Tingkat Efektifitas digunakan untuk mengukur upaya pemungutan Penerimaan rumah sakit yang telah dilakukan. Rumus efektivitas yang digunakan adalah:

Efektifitas $=\frac{\text { realisasi retribusi }}{\text { target retribusi }} x 100 \%$

b. Rasio Pertumbuhan

Tingkat pertumbuhan akan dilihat dari tahun ke tahun. Hal ini menunjukan kenaikan/penurunan penerimaan. Tingkat pertumbuhan yang positif menunjukan kinerja retribusi yang terus meningkat dan sebaliknya. Rumus pertumbuhan yang digunakan adalah :

$$
\text { Pertumbuhan }=\frac{P n-(P n-1)}{P n-1} \times 100 \%
$$

Dimana,

$\mathrm{Pn} \quad=$ realisasi pada $\mathrm{n}$

$\mathrm{Pn}-1$ = realisasi pada $\mathrm{n}-1$

$\mathrm{n}=$ Tahun anggaran

c. Analisis Selisih

Selisih digunakan untuk membandingkan antara target penerimaan dengan realisasi penerimaan dimana bertujuan untuk melihat kekurangan atau kelebihan dari satu sektor sehingga tidak salah pengalokasian anggaran pada sektor yang bukan prioritas. Rumus selisih yang digunakan adalah :

\section{Selisih $=$ Realisasi - Target}

Tahap kedua adalah penyusunan strategi yang diperlukan guna memperoleh solusi untuk optimalisasi peningkatan Penerimaan. Adapun tahapan ini dibagi beberapa tahapan. Pertama, Tahapan Input Strategi, dimana dalam tahap ini mengunakan Analisis Faktor 
Internal dan Eksternal (Solihin 2012) yang diringkas agar dapat dilakukan analisis dengan menggunakan Tabel/Matriks Evaluasi Internal-Ekternal (Matriks IFE/EFE), dengan memberikan bobot serta peringkat untuk masing-masing faktor yang mencerminkan tingkat kepentingan suatu faktor dibandingkan faktor lainnya (David 2010). Kedua, Tahapan Pencocokan Strategi dimana memakai Matrik Internal-Eksternal (Matriks IE) yang bertujuan untuk mengelompokan dalam tiga strategi utama yaitu strategi pertumbuhan, stabilitas, dan penciutan (David 2010). Selain memakai Matriks IE juga dipakai Analisis SWOT yang merupakan gabungan berbagai indikator yang terdapat dalam kekuatan, kelemahan, peluang, dan ancaman (Solihin 2012). Namun tidak semua rencana strategis yang disusun digunakan seluruhnya, strategi yang dipilih adalah strategi yang dapat memecahkan isu strategis. Ketiga, Tahapan Keputusan Strategi, dimana dalam tahap ini memakai Analisis QSPM yang merupakan tahap keputusan strategi yang akan dilakukan berdasarkan alternatif solusi yang didapat dari langkah pertama sampai ketiga sehingga akan menentukan daya tarik relatif dari berbagai strategi berdasarkan sejauh mana faktor-faktor sukses kritis internal ekternal dimanfaatkan atau diperbaiki sehingga akan menghasilkan prioritas strategi yang akan dilakukan (David 2010).

\section{HASIL DAN PEMBAHASAN}

\section{Analisis Potensi Penerimaan RSUD-HD}

Berdasarkan hasil pengamatan lapangan, diperoleh informasi bahwa sejak tahun 2008 sampai dengan 2016 belum pernah ada perhitungan perkiraan potensi penerimaan sehingga di jangka waktu tersebut dalam menentukan target hanya dua kali memakai metode prakiraan pendapatan. Pada periode waktu tersebut telah banyak perubahan yang terjadi di
Rumah Sakit Umum Daerah Hasanuddin Damrah, baik itu penambahan poli spesialis, ruang perawatan, sarana penunjang medis dan non medis maupun potensi penerimaan yang lain. Dari semua perhitungan perkiraan potensi penerimaan dari pelayanan kesehatan dan sarana kesehatan, maka didapatlah perhitungan potensi penerimaan secara keseluruhan.

Tabel 1. Potensi Penerimaan RSUDHD Tahun 2016

\begin{tabular}{|c|c|c|}
\hline No & Sektor & $\begin{array}{c}\text { Potensi } \\
\text { Penerimaan } \\
\text { (dalam juta) }\end{array}$ \\
\hline 1 & $\begin{array}{l}\text { Pelayanan } \\
\text { Kesehatan }\end{array}$ & \\
\hline \multirow{3}{*}{2} & $\begin{array}{l}\text { a. Rawat Jalan } \\
\text { b. Rawat Inap }\end{array}$ & $\begin{array}{r}2.169 \\
17.082\end{array}$ \\
\hline & Sewa Sarana & \\
\hline & $\begin{array}{l}\text { a. Penunjang Medis } \\
\text { b. Penunjang Non } \\
\text { Medis }\end{array}$ & $\begin{array}{r}17.481 \\
106 \\
\end{array}$ \\
\hline & Jumlah & 36.838 \\
\hline
\end{tabular}

Sumber : RSUD-HD 2016 (diolah)

Berdarkan Tabel 1, besaran potensi penerimaan secara keseluruhan sebesar Rp. 36.838.705.685, sektor yang besar sumbangannya terhadap total penerimaan adalah sektor rawat inap dan penunjang medis. Besarnya sumbangan sektor rawat inap dikarenakan unsur pembentuk penerimaan tidak hanya pemberian tindakan atau pelayanan saja tetapi juga sewa kamar, dan paket gizi. Sedangkan pada penunjang medis, besarnya sumbangan penerimaan terhadap total penerimaan dikarenakan selain pasien RSUD-HD juga karena pasien dari luar RSUD-HD, biasanya dari klinik kesehatan atau praktek dokter mandiri dimana mereka memerlukan dukungan dari sarana kesehatan penunjang medis dari RSUDHD.

Berdasarkan data realisasi yang dicapai telah dapat melampaui target yang telah ditetapkan oleh pihak Pemerintah Daerah Kabupaten Bengkulu Selatan pada tahun 2016, begitupun dengan tahun- 
tahun sebelumnya mulai dari tahun 2012 sampai dengan 2015 selalu melampaui target yang telah ditetapkan.

Tabel 2. Capaian Realisasi terhadap Target Penerimaan RSUDHD Tahun 2008-2016

\begin{tabular}{crr}
\hline Tahun & \multicolumn{1}{c}{$\begin{array}{c}\text { Target } \\
\text { (dalam juta) }\end{array}$} & $\begin{array}{c}\text { Realisasi } \\
\text { (dalam juta) }\end{array}$ \\
\hline 2008 & 9.868 & 5.095 \\
2009 & 9.868 & 6.327 \\
2010 & 6.700 & 4.138 \\
2011 & 6.000 & 5.428 \\
2012 & 6.654 & 7.421 \\
2013 & 7.500 & 9.161 \\
2014 & 16.000 & 19.127 \\
2015 & 23.000 & 25.673 \\
2016 & 27.850 & 32.429 \\
\hline
\end{tabular}

Sumber : RSUD-HD 2008-2016

Namun bila pelayanan RSUD-HD ini ditingkatkan dan dikembangkan serta penyelenggaraan pengelolaan penerimaannya dikelola dengan baik dan benar, maka setidaknya perkiraan potensi yang telah dihitung tersebut diharapkan mendekati potensi di lapangan yang sebenarnya. Berdasarkan Tabel 1, bahwa potensi penerimaan sebesar Rp. 36.838.705.685 hal ini berarti pada tahun 2016 Pemerintah Kabupaten Bengkulu Selatan mengalami kehilangan penerimaannya sebesar Rp. 4.409.249.999.

\section{Analisis Kinerja Penerimaan RSUD- HD}

$\begin{array}{ccc}\text { Untuk } & \text { mengukur } & \text { kinerja } \\ \text { penerimaan } & \text { menggunakan } & \text { rasio }\end{array}$ effektifitas, pertumbuhan, selisih. Rasio efektifitas ini menggambarkan kemampuan RSUD-HD dalam merealisasikan penerimaan yang direncanakan lalu dibandingkan dengan target yang ditetapkan.

Dari Tabel 3 terlihat bagaimana kinerja penerimaan dalam merealisasikan penerimaannya. Dari tahun 2008-2011 termasuk buruk, hal ini terlihat dari realisasi penerimaan yang selalu tidak mampu memenuhi target yang telah ditetapkan. Semenjak dipenghujung tahun 2011 dengan manajemen yang baru berimbas pula pada penerimaan RSUDHD. Dari tahun 2012-2016 menjadi baik, hal ini terlihat dari realisasi penerimaan yang selalu mampu melampaui 100\% target yang telah ditetapkan. Dari Tabel 3 keputusan menurunkan target tidak menjamin realisasinya akan melampaui target tersebut, dan pada saat target mulai dinaikan di tahun 2012 maka realisasi juga selalu melampaui target hal ini terjadi karena manajemen penerimaan berusaha mengurangi kebocoran penerimaan pada sektor-sektor penerimaan dan ruangan pelayanan serta berusaha menggali potensi penerimaan yang ada dengan peningkatan pelayanan. Sehingga penerimaan yang didapat selalu maksimal. Namun bila kita bandingkan dengan perhitungan potensi penerimaan bahwa target penerimaan masih dapat ditingkatkan, sehingga dapat lebih menyumbangkan penerimaan yang lebih banyak lagi dalam rangka peningkatan pelayanan.

Untuk mengetahui bagaimana perkembangan kinerja keuangan RSUDHD serta kecenderungannya, baik berupa kenaikan atau penurunan kinerja selama kurun waktu tertentu maka dipakailah Rasio Pertumbuhan yang juga mengukur seberapa besar kemampuan RSUD-HD dalam mempertahankan dan meningkatkan keberhasilannya yang telah dicapai dari periode ke periode berikutnya.

Berdasarkan Tabel 3 terlihat bahwa pada tahun 2010 tingkat pertumbuhan realisasi penerimaan bernilai negatif yang berarti bahwa terjadinya penurunan kinerja penerimaan atas tahun tahun sebelumnya. Sedangkan mulai tahun 2011 sampai dengan 2016 tingkat pertumbuhan realisasi penerimaan selalu bernilai positif yang berarti bahwa kinerja penerimaan pada tahun tersebut terus meningkat. 
Walaupun positif tetapi tingkat pertumbuhan penerimaan dari tahun 2011 sampai dengan 2016 cukup berfluktuatif dimana hal ini menandakan bahwa RSUDHD harus selalu berusaha untuk mempertahankan kinerja atas tahun sebelumnya dan berusaha meningkatkannya pada tahun berikutnya, sehingga tingkat kinerja tidak terlalu fluktuatif dan selalu cenderung meningkat.

Tabel 3. Kinerja Penerimaan RSUD-HD Tahun 2008-2016

\begin{tabular}{|c|c|c|c|c|c|c|}
\hline \multirow{3}{*}{ Tahun } & \multicolumn{2}{|c|}{ Penerimaan } & \multicolumn{4}{|c|}{ Kinerja Penerimaan } \\
\hline & \multirow{2}{*}{$\begin{array}{c}\text { Target } \\
\text { (dalam juta) }\end{array}$} & \multirow{2}{*}{$\begin{array}{c}\text { Realisasi } \\
\text { (dalam juta) }\end{array}$} & \multicolumn{2}{|c|}{ Pertumbuhan } & \multirow{2}{*}{$\begin{array}{c}\text { Effektivitas } \\
(\%)\end{array}$} & \multirow{2}{*}{$\begin{array}{c}\text { Selisih } \\
(\%)\end{array}$} \\
\hline & & & Target $(\%)$ & Realisasi (\%) & & \\
\hline 2008 & 9.868 & 5.095 & & & 51,64 & $-48,36$ \\
\hline 2009 & 9.868 & 6.327 & 0 & 24,18 & 64,12 & $-35,88$ \\
\hline 2010 & 6.700 & 4.138 & -32 & $-34,59$ & 61,77 & $-38,23$ \\
\hline 2011 & 6.000 & 5.428 & -10 & 31,17 & 90,48 & $-9,52$ \\
\hline 2012 & 6.654 & 7.421 & 11 & 36,70 & 111,53 & 11,53 \\
\hline 2013 & 7.500 & 9.161 & 13 & 23,45 & 122,15 & 22,15 \\
\hline 2014 & 16.000 & 19.127 & 113 & 108,78 & 119,55 & 19,55 \\
\hline 2015 & 23.000 & 25.673 & 44 & 34,22 & 111,63 & 11,63 \\
\hline 2016 & 27.850 & 32.429 & 21 & 26,31 & 116,44 & 16,44 \\
\hline
\end{tabular}

Sumber : RSUD-HD 2008-2016 (diolah)

Untuk mengetahui tingkat efektifitas dalam pencapaian target pendapatan, diukur dengan analisis selisih yang juga dapat mengetahui informasi awal tentang ada tidaknya unsur penyimpangan penerimaan. Berdasarkan Tabel 3 terlihat bahwa mulai tahun 2008 sampai dengan 2011 tingkat selisih kurang antara realisasi dengan pertumbuhan semakin berkurang dan mengecil. Sedangkan pada tahun 2012 sampai dengan 2016 tingkat selisih lebih antara realisasi dengan target selalu meningkat dan membesar. Hal ini menandakan tingkat selisih pencapaian realisasi dari tahun ke tahun cenderung semakin naik. Hal ini tidak dapat menjadikan acuan dari selisih antara target dengan realisasi karena adanya penetapan target yang menurun dan naik secara drastis. Bila dilihat secara presentase tingkat selisih penerimaan dari tahun 2008 sampai dengan 2016 sangatlah fluktuatif hal ini dikarenakan penetapan target yang tidak proporsional terhadap realisasi tahun sebelumnya sehingga ada beberapa tahun yang penetapan targetnya terlalu dekat selisihnya dengan realisasi tahun sebelumnya dan ada beberapa tahun yang terlalu jauh selisihnya dengan realisasi tahun sebelumnya, karena itu diperlukan perhitungan potensi penerimaan setiap tahun.

Untuk melihat kinerja dan permasalahan yang ada pada RSUD-HD maka haruslah diketahui kinerja penerimaan dan permasalahan yang ada dari sektor paling bawah yaitu ruangan pelayanan. Dari akumulasi seluruh sektor penerimaan tersebut, maka dicarilah dari sektor mana yang melebihi target yang ditetapkan, dan sektor mana yang kurang dari target yang ditetapkan, serta juga harus dilihat selisih kenaikan atau penurunannya. Sehingga dengan diketahui sektor mana yang melebihi atau kurang dari target dan diketahui juga tingkat selisih kenaikan atau penurunannya maka akan dicari apa yang menyebabkan terjadinya selisih tersebut. 


\section{STRATEGI PENINGKATAN PENERIMAAN RUMAH SAKIT DI KABUPATEN BENGKULU SELATAN}

\section{Tahapan Input Strategi}

Tahap input dalam kerangka kerja perumusan strategi pada penelitian ini terdiri atas matriks IFE dan matriks EFE. Informasi yang berasal dari tahap input ini memberikan informasi dasar untuk matriks di tahap pencocokkan dan tahap keputusan. Matriks IFE/EFE menggambarkan berbagai faktor internal yang terdapat pada RSUD-HD, sehingga dapat membuat keputusan alternatif strategi solusi. Matriks IFE mempunyai bobot 0,0 (tidak penting) sampai dengan 1,0 (sangat Penting), dengan nilai rating antara 1 (kelemahan utama) sampai dengan 4 (kekuatan utama) dengan jumlah skor 2,5 (David 2010).

Berdasarkan hasil matriks IFE untuk elemen kekuatan diperoleh skor sebesar 1,966, sedangkan skor untuk elemen kelemahan sebesar 0,708. Hal ini menunjukan bahwa seluruh responden memberikan pandangan yang cukup tinggi pada faktor kekuatan dan respon yang relatif kecil untuk faktor kelemahan. Sedangkan untuk skor faktor strategis internal mempunyai skor 2,674. Hal ini menunjukan bahwa dalam kajian ini kekuatan internal secara keseluruhan memiliki posisi yang kuat/diatas rata-rata dalam kelemahan internal secara keseluruhan, maka dapat dikatakan bahwa peningkatan penerimaan rumah sakit di Kabupaten Bengkulu Selatan mampu memanfaatkan kekuatan yang dimiliki untuk mengatasi kelemahan yang ada.

Sedangkan hasil dari matriks EFE untuk elemen peluang diperoleh skor sebesar 1,634, sedangkan skor untuk elemen ancaman sebesar 1,249. Hal ini menunjukan bahwa seluruh responden memberikan respon yang cukup tinggi pada faktor peluang dan respon yang relatif kecil untuk faktor ancaman.
Sedangkan untuk skor faktor strategis eksternal mempunyai skor 2,883 . Hal ini menunjukan bahwa dalam kajian ini peluang ekstrenal secara keseluruhan memiliki posisi yang kuat/diatas rata-rata dalam ancaman eksternal secara keseluruhan., maka dapat dikatakan bahwa peningkatan penerimaan rumah sakit di Kabupaten Bengkulu Selatan sangat prospektif untuk memanfaatkan peluang yang ada dan mampu meminimalkan pengaruh negatif dari ancaman yang ada.

\section{Tahapan Pencocokan Strategi}

Dalam penelitian ini analisis pada tahap pencocokkan menggunakan matriks SWOT dan matriks IE. Pada analisis lingkungan dan matriks IFE/EFE terdahulu ditemukan berbagai faktor kekuatan, kelemahan, peluang, dan ancaman yang berpengaruh terhadap peningkatan penerimaan rumah sakit. Dari berbagai faktor yang ada tersebut maka dapat dihasilkan beberapa strategi alternatif yang dihasilkan dari analisis SWOT, yaitu :

a. Strategi S-O (Strenght-Opportunities) Strategi ini disusun dengan memakai kekuatan yang dimiliki untuk memanfaatkan peluang yang ada, sehingga diperoleh beberapa strategi :

1. Optimalisasi Pemanfaatan SDM serta sarana dan prasarana kesehatan

2. Pengembangan dan peningkatkan pelayanan kesehatan

3. Peningkatan Peralatan Pendukung Penerimaan

4. Peningkatan koordinasi dan kerjasama dengan stake holder terkait

b. Strategi W-O (WeaknessesOpportinies)

Strategi ini disusun untuk mengatasi kelemahan-kelemahan yang dimiliki dengan memanfaatkan seluruh 
peluang yang ada, sehingga diperoleh beberapa strategi :

1. Menciptakan manajemen farmasi yang maksimal

2. Pembuatan farmasi tambahan pada lokasi stategis

3. Melakukan kerjasama rujukan dan menggiatkan promkes

4. Peningkatan kapabilitas dan kompetensi SDM serta penambahan waktu pelayanan kesehatan

c. Strategi S-T (Strenght-Threats)

Strategi ini disusun dengan memakai kekuatan yang dimiliki untuk mengatasi ancaman yang ada, sehingga diperoleh strategi Penetapan kebijakan pemerintah berupa penyesuaian tarif dan sistem ketersediaan obat,

d. Strategi W-T (Weaknesses-Threats)

Strategi ini disusun dengan meminimalkan kelemahan dan mengatasi ancaman yang ada, sehingga strategi yang diperoleh adalah Peningkatan pengetahuan kesehatan masyarakat
Analisis Internal-Eksternal (Matriks

IE)

\section{Peningkatan Penerimaan Rumah Sakit}

Pada analisis IE dipakai untuk mencari strategi secara umum dalam peningkatan penerimaan rumah sakit. Matriks IE ini didasarkan pada dua dimensi kunci yaitu skor total IFE yang diberi bobot pada sumbu $\mathrm{X}$ dan total EFE yang diberi bobot pada sumbu Y. Dari nilai total IFE sebesar 2,674, hal ini menunjukan posisi internal yang sedang dan untuk nilai total EFE adalah 2,883 hal ini menunjukan posisi eksternal yang sedang.

Pada Gambar 3, posisi peningkatan penerimaan rumah sakit di Kabupaten Bengkulu Selatan berada pada posisi sel ke V, artinya RSUD-HD dalam melaksanakan pelayanan kesehatan sehingga menghasilkan penerimaan berada pada posisi menjaga/memelihara dan mempertahankan/stabilitas, yaitu sebuah strategi yang lebih banyak mengedepankan penetrasi pasar dan pengembangan pelayanan kesehatannya.

Total Skor IFE

\begin{tabular}{|c|c|c|c|c|}
\hline & & $\begin{array}{l}\text { Kuat } \\
3-4\end{array}$ & $\begin{array}{l}\text { Sedang } \\
2-2,9\end{array}$ & $\begin{array}{l}\text { Lemah } \\
1-1,99\end{array}$ \\
\hline & 4 & & & 2 \\
\hline & & I & II & III \\
\hline $\begin{array}{l}\text { Tinggi } \\
3-4\end{array}$ & & $\begin{array}{l}\text { Pertumbuhan dan } \\
\text { membangun/bina }\end{array}$ & $\begin{array}{l}\text { Pertumbuhan dan } \\
\text { membangun/bina }\end{array}$ & $\begin{array}{l}\text { Menjaga/memelihara dan } \\
\text { Mempertahankan/stabilitas }\end{array}$ \\
\hline $\begin{array}{l}\text { Sedang } \\
2-2,99\end{array}$ & 3 & $\begin{array}{c}\text { IV } \\
\text { Pertumbuhan dan } \\
\text { membangun/bina }\end{array}$ & $\begin{array}{c}\mathrm{V} \\
\text { Menjaga/memelihara dan } \\
\text { Mempertahankan/stabilitas }\end{array}$ & $\begin{array}{c}\text { VI } \\
\text { Panen/Divestasi }\end{array}$ \\
\hline $\begin{array}{l}\text { Rendah } \\
1-1,99\end{array}$ & 2 & $\begin{array}{c}\text { VII } \\
\text { Menjaga/memelihara dan } \\
\text { Mempertahankan/stabilitas }\end{array}$ & $\begin{array}{c}\text { VIII } \\
\text { Panen/Divestasi }\end{array}$ & $\begin{array}{c}\text { IX } \\
\text { Panen/Divestasi }\end{array}$ \\
\hline
\end{tabular}

Gambar 3. Matriks Internal-Eksternal (IE) 


\section{Tahapan Keputusan Strategi}

Untuk menentukan prioritas strategi peningkatan penerimaan RSU-HD alat yang digunakan adalah Matriks QSPM. Menurut David (2010) QSPM adalah alat yang memungkinkan ahli strategi untuk mengevaluasi strategi alternatif secara obyektif, berdasarkan pada faktor-faktor kritis untuk sukses internal dan eksternal. Analisis QSPM merupakan lanjutan dari analisis SWOT. Dari rumusan strategi yang didapat dari analisis SWOT kemudian dianalisa dengan cara memberikan nilai daya tarik (Attractive Score/AS) pada masingmasing faktor strategis.

Tabel 4. Hasil Analisis QSPM Perumusan Prioritas Strategi Peningkatan Penerimaan Rumah Sakit

\begin{tabular}{|c|c|c|c|}
\hline No & Alternatif Strategi & TAS & Peringkat \\
\hline 1 & $\begin{array}{l}\text { Optimalisasi pemanfaatan SDM serta sarana dan } \\
\text { prasarana kesehatan }\end{array}$ & 5,861 & 3 \\
\hline 2 & $\begin{array}{l}\text { Pengembangan dan peningkatkan pelayanan } \\
\text { kesehatan }\end{array}$ & 6,352 & 1 \\
\hline 3 & Peningkatan peralatan pendukung penerimaan & 6.090 & 2 \\
\hline 4 & $\begin{array}{l}\text { Peningkatan koordinasi dan kerjasama dengan stake } \\
\text { holder terkait }\end{array}$ & 5,599 & 5 \\
\hline 5 & $\begin{array}{l}\text { Menciptakan kemampuan manajemen farmasi yang } \\
\text { maksimal }\end{array}$ & 4,535 & 7 \\
\hline 6 & Pembuatan farmasi tambahan pada lokasi stategis & 4,449 & 8 \\
\hline 7 & $\begin{array}{l}\text { Melakukan kerjasama rujukan dan menggiatkan } \\
\text { promkes }\end{array}$ & 5,063 & 6 \\
\hline 8 & $\begin{array}{l}\text { Peningkatan kapabilitas dan kompetensi SDM serta } \\
\text { penambahan waktu pelayanan kesehatan }\end{array}$ & 5,662 & 4 \\
\hline 9 & $\begin{array}{l}\text { Penetapan kebijakan pemerintah berupa penyesuaian } \\
\text { tarif dan sistem ketersediaan obat }\end{array}$ & 4,409 & 10 \\
\hline 10 & Peningkatan pengetahuan kesehatan masyarakat & 4,437 & 9 \\
\hline
\end{tabular}

Berdasarkan hasil urutan peringkat strategi pada Tabel 4 maka dibuatlah program dan kegiatan dalam rangka peningkatan penerimaan rumah sakit di Kabupaten Bengkulu Selatan, sehingga akan berdampak pada peningkatan pelayanan kesehatan RSUD-HD sehingga berdampak pula terpenuhinya kebutuhan masyarakat terhadap akses pelayanan kesehatan yang baik dan berkualitas akan berjalan sesuai dengan yang diharapkan.

\section{KESIMPULAN}

Berdasarkan hasil dan pembahasan yang dilakukan pada kajian mengenai peningkatan penerimaan rumah sakit RSUD-HD Kabupaten Bengkulu
Selatan, maka diperoleh beberapa kesimpulan sebagai berikut :

1. RSUD-HD belum mampu atau mempunyai keterbatasan dalam hal perhitungan potensi/target penerimaan sehingga target yang ditetapkan belumlah mendekati dari potensi penerimaan yang sebenarnya.

2. Kinerja penerimaan mulai tahun 20122016, sejak pembenahan manajemen baik administrasi maupun pelayanan kesehatan kinerja penerimaan cenderung tinggi. Penurunan target penerimaan bukanlah solusi agar realisasi mampu melampaui target, secara umum penerimaan rumah sakit di Kabupaten Bengkulu Selatan sejak tahun 2012 selalu melebihi dari target yang ditetapkan 
Tabel 5. Strategi, Program, dan Kegiatan Peningkatan Penerimaan Rumah Sakit

\begin{tabular}{|c|c|c|c|}
\hline No & Strategi & Program & Kegiatan \\
\hline 1 & $\begin{array}{l}\text { Pengembangan dan } \\
\text { peningkatkan pelayanan } \\
\text { kesehatan }\end{array}$ & $\begin{array}{l}\text { Pelatihan dan } \\
\text { peningkatan pelayanan } \\
\text { kesehatan }\end{array}$ & $\begin{array}{l}\text { a. Pelatihan character } \\
\text { building dan pemilihan } \\
\text { tenaga medis dan } \\
\text { paramedis terbaik } \\
\text { b. Pembuatan alur } \\
\text { pelayanan yang singkat } \\
\text { dan nyaman } \\
\text { c. Pemetaan } \\
\text { pengembangan } \\
\text { pelayanan }\end{array}$ \\
\hline 2 & $\begin{array}{l}\text { Peningkatan peralatan } \\
\text { pendukung penerimaan }\end{array}$ & $\begin{array}{l}\text { Pengembangan } \\
\text { pengelolaan keuangan } \\
\text { mandiri (BLUD) }\end{array}$ & $\begin{array}{l}\text { Pengadaan peralatan } \\
\text { billing system }\end{array}$ \\
\hline 3 & $\begin{array}{l}\text { Optimalisasi pemanfaatan } \\
\text { SDM serta sarana dan } \\
\text { prasarana }\end{array}$ & $\begin{array}{l}\text { Pemeliharaan sarana dan } \\
\text { prasarana kesehatan } \\
\text { serta pemanfaatan } \\
\text { sumber daya aparatur }\end{array}$ & $\begin{array}{l}\text { Pemeliharaan alkes dan } \\
\text { penempatan tenaga medis } \\
\text { dan medis yang mampu }\end{array}$ \\
\hline 4 & $\begin{array}{l}\text { Peningkatan kapabilitas } \\
\text { dan kompetensi SDM } \\
\text { serta penambahan waktu } \\
\text { pelayanan kesehatan }\end{array}$ & $\begin{array}{l}\text { Peningkatan kapasitas } \\
\text { sumber daya aparatur } \\
\text { dan pelayanan kesehatan }\end{array}$ & $\begin{array}{l}\text { a. Pendidikan dan } \\
\text { pelatihan bagi tenaga } \\
\text { medis dan paramedis } \\
\text { b. Penertiban jam layanan } \\
\text { dan penambahan jam } \\
\text { layanan }\end{array}$ \\
\hline 5 & $\begin{array}{l}\text { Peningkatan koordinasi } \\
\text { dan kerjasama dengan } \\
\text { stake holder terkait }\end{array}$ & $\begin{array}{l}\text { Koordinasi dan } \\
\text { kerjasama kesehatan }\end{array}$ & $\begin{array}{l}\text { Koordinasi dan kerjasama } \\
\text { antar RSUD kabupaten } \\
\text { tetangga }\end{array}$ \\
\hline
\end{tabular}

3. Manajemen penerimaan belum mempunyai catatan penerimaan yang mendalam. Secara umum yang menyebabkan selisih kurang/lebih yang terjadi adalah dikarenakan faktor variasi SDM, beberapa kurangnya sarana, citra RSUD-HD, manajemen farmasi, dan waktu pelayanan.

4. Berdasarkan hasil analisis QSPM didapat prioritas untuk peningkatan penerimaan RSUD-HD yaitu Strategi Pengembangan dan peningkatkan pelayanan kesehatan.

\section{DAFTAR PUSTAKA}

David FR. 2010. Manajemen Strategis.

Buku 1 Edisi 12. Jakarta (ID):

Salemba Empat.

[DPPKAD] Dinas Pendapatan,

Pengelolaan Keuangan, dan Aset daerah. 2011-2015. APBD

Kabupaten Bengkulu Selatan. Manna (ID). DPPKAD.

Kasmir. 2008. Analisis Laporan Keuangan. Jakarta (ID): Rajawali Pers.

[Kemendagri] Kementerian Dalam Negeri. 2007. Peraturan Menteri Dalam Negeri No. 61 Tahun 2007 tentang Pedoman Teknis Pengelolaan Keuangan Badan Layanan Umum Daerah. Jakarta (ID) : Kemendagri.

[Kemenkeu] Kementerian Keuangan. 2016. Anggaran Kesehatan 20102015. [Internet].[diunduh 2016 Desember 3]. Tersedia pada : http//www.anggaran.depkeu.go.id/d ja/athumbs/apbn/KESEHATAN1.p df. 
Mahmudi. 2010. Manajemen Keuangan Daerah. Jakarta (ID): Erlangga.

Pemerintah Republik Indonesia. 2009. Undang-Undang No. 44 Tahun 2009 tentang Rumah Sakit. Jakarta (ID). Sekretariat Negara.

Pemerintah Republik Indonesia. 2011. Undang-Undang Nomor 24 Tahun 2011 tentang Badan Penyelenggara Jaminan Sosial. Jakarta (ID). Sekretariat Negara.

[Pemkab B/S] Pemerintah Kabupaten Bengkulu Selatan. 2014. Keputusan Bupati Bengkulu Selatan Nomor: 445/582 Tahun 2014 tentang Penetapan RSUD Hasanuddin Damrah sebagai Satuan Kerja Perangkat Daerah (SKPD) yang menerapkan Pola Pengelolaan
Keuangan Badan Layanan Umum Daerah (PPK-BLUD RSUD-HD). Manna (ID) : Pemkab B/S.

Restianto YE, Bawono IR. 2015. Pengelolaan Keuangan BLU/BLUD. Purwokerto (ID): Unit Penerbit dan Percetakan STIM YKPN.

[RSUD-HD] Rumah Sakit Umum Daerah Hasanuddin Damrah. 2008-2016. Laporan Keuangan Bendahara Penerimaan. Manna (ID). RSUDHD.

[RSUD-HD] Rumah Sakit Umum Daerah Hasanuddin Damrah. 2016. Laporan Sistem Informasi Rumah Sakit. Manna (ID). RSUD-HD.

Solihin I. 2012. Manajemen Strategik. Jakarta (ID): Erlangga. 